
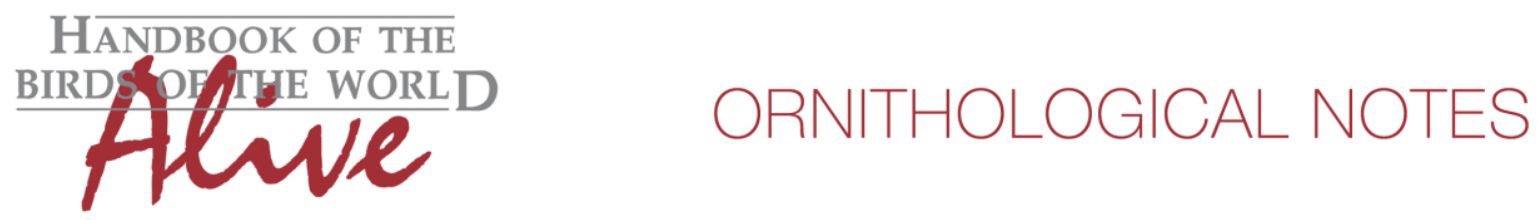

\title{
Notes on the vocalizations of Green Manakin (Chloropipo holochlora)
}

Peter Boesman

In the following we briefly analyze and compare voice of the different races of Green Manakin (Chloropipo holochlora). We also try to quantify the extent of any vocal differences using the criteria proposed by Tobias et al. (2010), as a support for taxonomic review. We have made use of sound recordings available on-line from Xeno Canto (XC).

litae and suffusa occur west of the Andes in the Chocó region, while holochlora and viridior occur in the foothills east of the Andes. Presumed song or advertising call of both groups is quite different (although it should be mentioned that we have not found recordings of suffusa and viridior):

litae $(n=5)$

A sweet thin whistle, initially sharply rising, then gradually falling in pitch (Fig. 1).

$\begin{array}{ll}\text { length } & 0.36-0.57 \mathrm{~s} \\ \text { freq. range } & 1500-2500 \mathrm{~Hz} \\ \text { min freq. } & 3350-4500 \mathrm{~Hz} \\ \text { max. freq. } & 5400-6000 \mathrm{~Hz} \\ \text { location max. freq. } & 0.025-0.05 \mathrm{~s}\end{array}$

holochlora $(n=4)$

A thin gradually rising whistle with slight drop at the end (Fig. 1)

$\begin{array}{ll}\text { length } & 0.23-0.66 \mathrm{~s} \\ \text { freq. range } & 1500-2400 \mathrm{~Hz} \\ \text { min freq. } & 2600-4000 \mathrm{~Hz} \\ \text { max. freq. } & 5000-6300 \mathrm{~Hz} \\ \text { location max. freq. } & 0.23-0.65 \mathrm{~s}\end{array}$

We assume here that this single whistle is the song or advertising call and thus the main vocalization, despite not being described in Snow (2015), but the structural similarity with the closely related $C$. uniformis leaves little doubt (Fig. 1).

Basic sound parameters are similar, the rising vs. falling whistle can however be quantified by e.g. location of the max. frequency (score 4). Note shape is clearly different with litae always first briefly rising, then falling while holochlora steadily rising with a steep drop at end (1). When applying Tobias criteria this results in a vocal score of 4-5. 


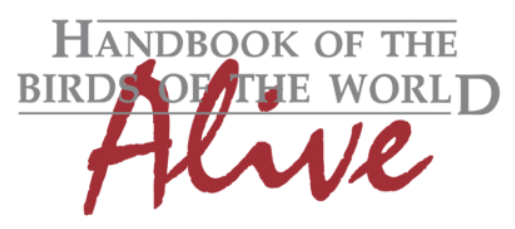

\section{ORNITHOLOGICAL NOTES}
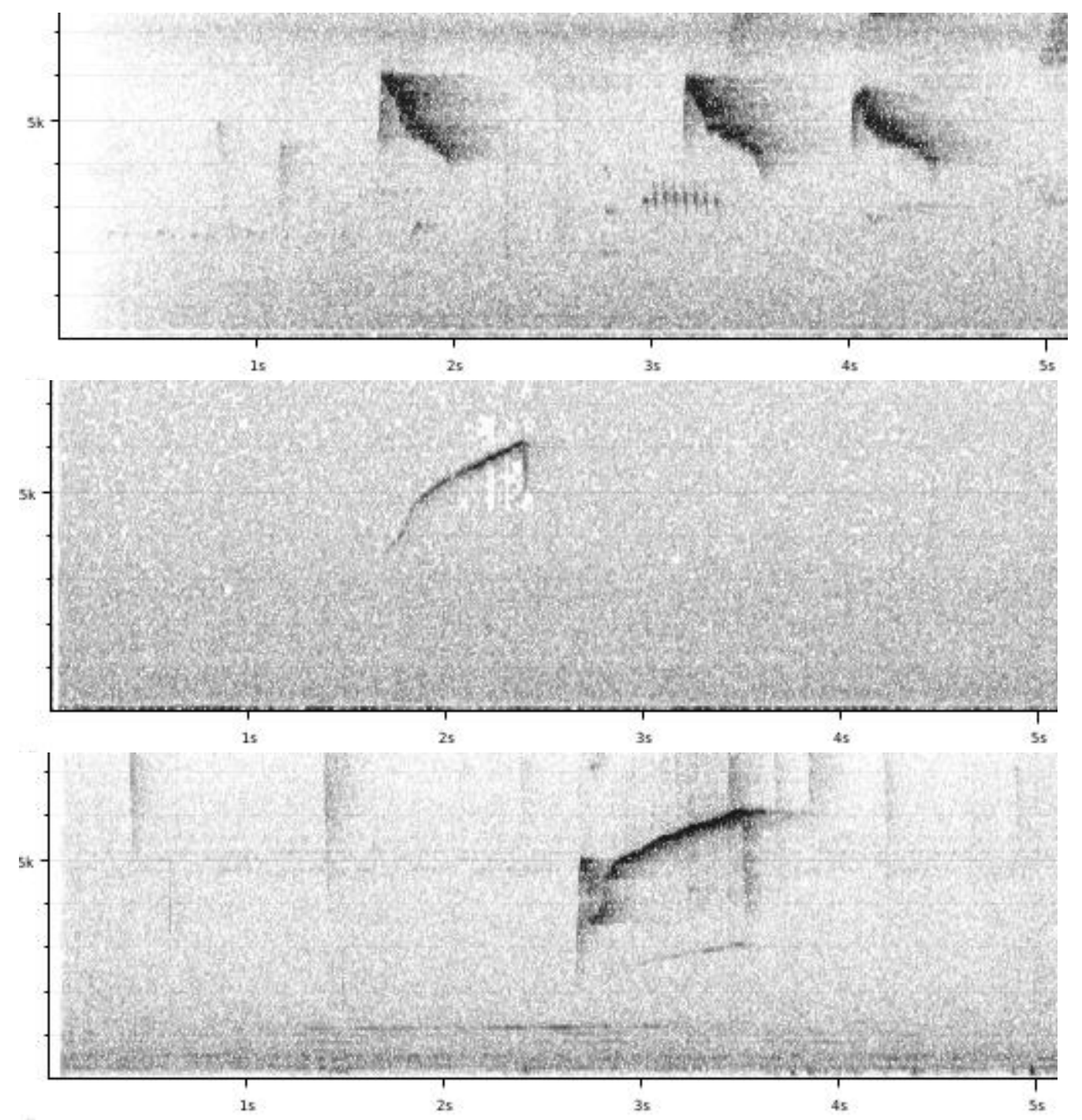

Figure 1: from top to bottom: typical song of C.h.litae, C.h holochlora and C. uniformis

This note was finalized on 4th May 2015, using sound recordings available on-line at that moment. We would like to thank in particular the sound recordists who placed their recordings for this species on XC: Peter Boesman, Eric DeFonso, Jerome Fischer, Olaf Jahn, Niels Krabbe and John V Moore.

\section{References}

Snow, D. (2015). Green Manakin (Chloropipo holochlora). In: del Hoyo, J., Elliott, A., Sargatal, J., Christie, D.A. \& de Juana, E. (eds.). Handbook of the Birds of the World Alive. Lynx Edicions, Barcelona. (retrieved from http://www.hbw.com/node/57101 on 1 May 2015).

Tobias, J.A., Seddon, N., Spottiswoode, C.N., Pilgrim, J.D., Fishpool, L.D.C. \& Collar, N.J. (2010). Quantitative criteria for species delimitation. Ibis 152(4): 724-746. 


\section{Recommended citation}

Boesman, P. (2016). Notes on the vocalizations of Green Manakin (Chloropipo holochlora). HBW Alive Ornithological Note 108. In: Handbook of the Birds of the World Alive. Lynx

Edicions, Barcelona. (retrieved from http://www.hbw.com/node/932013 on 2 August 2016). 